\title{
Long-term follow-up of pulmonary function in chronic eosinophilic pneumonia
}

\author{
J. Durieu*+, B. Wallaert*+, A-B. Tonnel*+ and the Groupe d'Etude en Pathologie \\ Interstitielle de la Société de Pathologie Thoracique du Nord
}

Long-term follow-up of pulmonary function in chronic eosinophilic pneumonia. J. Durieu, B. Wallaert, A-B. Tonnel and the Groupe d'Etude en Pathologie Interstitielle de la Société de Pathologie Thoracique du Nord. OERS Journals Ltd 1997.

ABSTRACT: The prognosis of chronic eosinophilic pneumonia (CEP) is usually good under corticosteroid therapy (CST). The main complications are relapses when treatment is tapered or discontinued. The aim of this retrospective, multicentre study was to evaluate the long-term consequences of CEP on pulmonary function tests.

Nineteen patients (mean \pm SEM age $51 \pm 16$ yrs) with CEP were studied. Lung function tests were performed at the time of diagnosis and at follow-up, and included flow-volume curve.

The results of the first pulmonary function test were normal in six patients, restrictive in nine, and obstructive in four. Relapses (recurrence of initial signs) occurred in nine patients. The last evaluation (mean \pm SEM follow-up of $49 \pm 44$ months, range 12-142 months) showed a complete recovery in 8 of the 19 patients. One patient developed bilateral apical fibrosis. The remaining 10 patients, exhibited obstructive pulmonary function without relapse of CEP at this time. Bronchoalveolar lavage (BAL) eosinophilia at the time of the initial evaluation tended to be higher $(p=0.05)$ in these 10 patients than in those with normal pulmonary function findings at follow-up.

This study demonstrates: firstly, that the development of an obstructive ventilatory defect is a common finding during the course of chronic eosinophilic pneumonia (CEP); secondly, that bronchial obstruction might appear despite the absence of clinical and radiological signs of relapse; and, thirdly, that a markedly increased bronchoalveolar lavage eosinophilia at the initial evaluation is associated with a higher risk of development of bronchial obstruction. These results suggest that pulmonary function tests should be included in the management of chronic eosinophilic pneumonia.

Eur Respir J 1997; 10: 286-291.

Chronic eosinophilic pneumonia (CEP) is a rare disorder, initially described by CARRINGTON et al. [1] and LiEBOw and CARRINGTON [2] in 1969. It usually occurs in middle-aged women, and symptoms include malaise, fever, night sweats, anorexia and weight loss, cough and dyspnoea. Diagnosis relies, firstly, on the association of such clinical signs with fluffy peripheral opacities on chest radiographs and blood or alveolar eosinophilia [3]; and, secondly, on the exclusion of other aetiological diagnoses, such as parasitic, mycotic, iatrogenous, vasculitis or granulomatous diseases. A pathological exclusion of such diseases may be required in some cases.

Systemic corticosteroid therapy leads to a dramatic improvement both of clinical and radiological signs, insomuch that it has been suggested as a diagnostic test. Relapses are the main complications during the course of CEP, when steroid therapy is tapered or discontinued, with $30 \%$ of patients requiring maintenance steroid therapy. Few data are available about long-term outcome in CEP. JEDERLINIC et al. [4] summarized cases in the literature, including 19 personal cases. However, lung function tests were only available in a few patients
*Clinique de Maladies Respiratoires, Hôpital A. Calmette, and INSERM U416, Institut Pasteur, Lille, France. +Groupe d'Etude en Pathologie Interstitielle (GEPI) de la Société de Pathologie Thoracique du Nord.

Correspondence: B. Wallaert

Clinique de Maladies Respiratoires

Hôpital A. Calmette

Boulevard du Professeur Leclerc

59037 Lille Cedex

France

\section{Keywords:}

Chronic eosinophilic pneumonia

follow-up

obstructive lung disease

Received: January 221996

Accepted after revision September 251996 and half of the cases with initial airflow obstruction had a prior history of asthma.

Recently, NAughton et al. [5] studied 12 patients over a mean period of 10.2 yrs. The overall prognosis was excellent in all cases, with low maintenance dose corticotherapy in 10 . Nevertheless, it is important to point out that relapse was defined by NAUGHTON et al. [5] as "a return of the original presenting symptoms with peripheral eosinophilia or radiological opacities" and did not include evaluation of lung function. We therefore report our experience in 19 patients, and show that obstructive lung disease is a frequent outcome in CEP, regardless of the classical criteria of relapse.

\section{Patients and methods}

\section{Patients}

Nineteen patients (16 females and 3 males) with CEP were included in a multicentre retrospective study. Diagnosis relied on suggestive clinical and radiological signs, 
an elevated blood or alveolar eosinophilia, and a dramatic improvement after induction of corticosteroid therapy. No patient had malignancy or vasculitis, or had received any drug associated with eosinophilic infiltration of the lung. Parasitic infestation was excluded by stool examination and analysis of serum samples. Serum precipitins and skin tests for Aspergillus fumigatus were negative in all cases. The clinical characteristics of the patients are summarized in table 1 . Mean \pm SEM age at diagnosis was $51 \pm 16$ yrs (range $20-80 \mathrm{yrs}$ ). All but one of the patients were nonsmokers. Patient No. 14 had a long previous history of tobacco smoke exposure. Nevertheless, she had stopped smoking many years prior to the diagnosis.

Twelve patients had a history of allergy with previous asthma and/or rhinitis and/or drug allergy in one patient (No. 18). Nasal polyps were present in patient No. 16. Sixteen patients had general symptoms at the initial evaluation, the most frequent being weight loss (13 cases). Respiratory symptoms were a constant finding, including dyspnoea and cough. Wheezes were present in six cases, four of them (Nos. 2, 7, 11 and 18) exhibiting a previous history of asthma.

The single extrathoracic manifestation was a peripheral motor neuropathy in patient No. 6. Churg Strauss syndrome was excluded on clinical and pathological data. Despite initial wheezing, the patient did not develop subsequent asthma. Neither recurent eosinophilia nor new extrathoracic manifestation were observed. Pathological examination of a neuromuscular biopsy did not show necrotizing vasculitis or extravascular granulomas. Finally, corticosteroid therapy led to a dramatic improvement and no maintenance steroid therapy was required.

Pathological examination of lung parenchyma was obtained in four patients. Transbronchial biopsies were initially performed in patients Nos. 11 and 19. They were normal in patient No. 11, and showed pulmonary eosinophilia in patient No. 19. Patient No. 3 had an open lung biopsy that showed an interstitial eosinophilic infiltration. One patient (No. 10) had perfibreoptic bronchial biopsies during the follow-up, which showed an eosinophilic bronchitis. At the same time, she developed an obstructive lung disease.

\section{Radiological data}

A posteroanterior chest radiograph was obtained in all patients at diagnosis. Fifteen patients had characteristic peripheral opacities, three had atypical opacities, and one had a normal chest radiograph. Computed tomography (CT)-scan was initially performed in 14 patients. Thirteen patients exhibited typical peripheral opacities. Typical concentric subpleural lines were present in patients Nos. 8 and 10. Mediastinal lymph nodes and peripheral cavities were also present in two (Nos. 14 and 19) and one case (No. 18), respectively. Unilateral radiological involvement was observed in two cases (Nos. 3 and 14). Chest roentgenography and CT-scan were normal at diagnosis in patient No. 11 in whom typical fluffy opacities only appeared 18 months later as the CEP relapsed.

\section{Biological data}

Blood samples were obtained in order to determine absolute blood cell count, erythrocyte sedimentation rate (ESR), and total serum immunoglobulin E (IgE) level. Hypereosinophilia was defined as an absolute blood eosinophil count above 500 cells $\cdot \mathrm{mm}^{-3}$. All patients but one (No. 3) had an elevated blood eosinophil count (mean \pm SEM 4,232 $\pm 3,461$, range $400-15,750$ cells $\cdot \mathrm{mm}^{-3}$ ). Bronchoalveolar lavage (BAL) was available in 17 cases. The first aliquot was analysed separately according to the European Respiratory Society (ERS) statements [6].

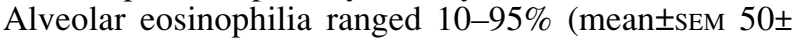
$28 \%$ ). ESR was normal ( $\leq 10 \mathrm{~mm}$ after $1 \mathrm{~h})$ in 4 of the 17 cases. Total serum IgE level was high in 15 cases (mean \pm SEM $580 \pm 696$, range $20-2,700 \mathrm{kU} \cdot \mathrm{L}^{-1}$; normal value $\left.<95 \mathrm{kU} \cdot \mathrm{L}^{-1}\right)$.

Table 1. - Epidemiological, clinical and biological features

\begin{tabular}{|c|c|c|c|c|c|c|c|c|c|}
\hline $\begin{array}{l}\mathrm{Pt} \\
\text { No. }\end{array}$ & Group & Sex & $\begin{array}{l}\text { Age } \\
\text { yrs }\end{array}$ & $\begin{array}{c}\text { Previous } \\
\text { A/R }\end{array}$ & Initial symptoms & $\begin{array}{c}\text { ESR } \\
\mathrm{mm} \cdot \mathrm{h}^{-1}\end{array}$ & $\begin{array}{l}\text { Serum IgE } \\
\text { level } \\
\text { KUI· } L^{-1}\end{array}$ & $\begin{array}{c}\text { Blood } \\
\text { eosinophils } \\
\text { cells } \cdot \mathrm{mm}^{-3}\end{array}$ & $\begin{array}{c}\text { BAL } \\
\text { eosinophils } \\
\%\end{array}$ \\
\hline 1 & A & $\mathrm{F}$ & 49 & $\mathrm{~A} / \mathrm{R}$ & F, NS, As, An, WL, DC, D & 101 & 20 & 3100 & 50 \\
\hline 2 & A & $\mathrm{F}$ & 67 & A & F, As, An, WL, DC, D & 10 & 1200 & 3000 & 15 \\
\hline 3 & A & $\mathrm{F}$ & 69 & - & WL, PC, D & ND & ND & 400 & 24 \\
\hline 4 & A & M & 49 & - & NS, As, WL, PC, D, P & 46 & 266 & 15750 & 20 \\
\hline 5 & A & $\mathrm{F}$ & 64 & - & F, NS, As, An, WL, DC, D & 76 & 232 & 7449 & 30 \\
\hline 6 & A & $\mathrm{F}$ & 66 & $\mathrm{R}$ & F, DC, D & 56 & 123 & 3556 & 35 \\
\hline 7 & A & $\mathrm{F}$ & 42 & A & $\mathrm{DC}, \mathrm{D}$ & 12 & 45 & 2200 & 64 \\
\hline 8 & A & $\mathrm{F}$ & 30 & $\mathrm{~A} / \mathrm{R}$ & $\mathrm{F}, \mathrm{NS}, \mathrm{As}, \mathrm{PC}, \mathrm{D}$ & 82 & 770 & 2900 & 40 \\
\hline 9 & A & M & 80 & - & As, An, WL, PC, D & 109 & 2700 & 1300 & 60 \\
\hline 10 & B & $\mathrm{F}$ & 44 & - & $\mathrm{D}$ & ND & 346 & 2600 & ND \\
\hline 11 & B & $\mathrm{F}$ & 40 & A & WL, DC & 2 & ND & 8300 & 30 \\
\hline 12 & B & $\mathrm{F}$ & 58 & A & F, NS, As, An, WL, DC, D & 100 & 102 & 2000 & 10 \\
\hline 13 & B & $\mathrm{M}$ & 20 & $\mathrm{R}$ & F, WL, DC, D & 17 & 885 & 6800 & 80 \\
\hline 14 & B & $\mathrm{F}$ & 40 & $\mathrm{R}$ & F, As, DC, D & 40 & 866 & 4026 & 78 \\
\hline 15 & B & $\mathrm{F}$ & 25 & $\mathrm{R}$ & As, An, WL, DC, D & 10 & 265 & 3200 & 73 \\
\hline 16 & B & $\mathrm{F}$ & 38 & $\mathrm{R}$ & WL, DC & 1 & 239 & 1683 & ND \\
\hline 17 & B & $\mathrm{F}$ & 64 & - & PC, H, D & 38 & 203 & 3564 & 95 \\
\hline 18 & B & $\mathrm{F}$ & 59 & A & F, NS, As, An, WL, PC, D, P & 140 & 137 & 3480 & 60 \\
\hline 19 & B & $\mathrm{F}$ & 67 & - & F, As, An, WL, PC, D & 58 & 1434 & 5100 & 95 \\
\hline
\end{tabular}

Pt: patient; M: male; F: female; A/R: asthma/rhinitis; F: fever; NS: night sweat; WL: weight loss; As: asthenia; An: anorexia; DC: dry cough; PC: productive cough; H: haemoptysis; D: dyspnoea; P: chest pain; ND: not determined. 


\section{Lung function tests}

All but two patients had initial pulmonary function tests before any corticosteroid treatment. Patients Nos. 6 and 16 did not perform initial tests because of severe respiratory impairment. Spirometry was performed following the American Thoracic Society (ATS) guidelines [7]. Normal values were defined as forced vital capacity (FVC) $\geq 80 \%$ of predicted value and forced expiratory volume in one second $(\mathrm{FEV} 1) \geq 80 \%$ pred. According to the ATS statement [8], an obstructive ventilatory defect was defined as a disproportionate reduction of FEV1 compared to FVC. Small airways disease was defined as a decrease of forced mid-expiratory flow (FEF25-75) by $\geq 40 \%$ compared to normal. Reversibility following $\beta_{2}$-mimetic challenge was defined as an increase of FEV1 by $12 \%$ of baseline and an absolute change of $200 \mathrm{~mL}$ [8], or an increase of FEF25-75 by $25 \%$ of baseline [9]. Restrictive ventilatory defect was defined as a reduction of FVC, with normal or increased FEV1/ FVC. Interpretation of the results of lung function tests was compared to clinical presentation in all cases.

\section{Statistical analysis}

When applicable, comparison between groups was performed using Mann-Whitney U-test for quantitative data and Chi-squared test for qualitative data. A p-value of less than 0.05 was considered to be statistically significant. Data are presented as mean \pm SEM.

\section{Results}

\section{First evaluation}

Pulmonary function tests were performed in 17 patients before initiating any corticotherapy (table 2). Results of pulmonary function tests were normal in four patients, restrictive in nine (FVC range 36-76\% pred), and obstructive in four. Three of the latter four patients were wheezy. In two cases (Nos. 6 and 16), a flow-volume curve was performed after initiation of corticotherapy and was normal despite initial wheezing in patient No. 6 .

\section{Short-term evolution}

All the patients initially received systemic corticotherapy as summarized in table 3 (mean \pm sem dose $50 \pm 17$ $\mathrm{mg}$ of prednisone, range $20-80 \mathrm{mg}$ ). The tapering rate was highly variable from one patient to another. Mean \pm SEM duration of initial steroid therapy was $18 \pm 18.7$ months (range 3-72 months). A dramatic improvement occurred in 17 cases, with resolution of clinical and radiological symptoms in a few days (table 3). A partial improvement with persisting radiological opacities occurred in two patients (Nos. 17 and 19).

\section{Follow-up}

Relapses. Relapses, as defined by recurrence of clinical and radiological signs, occurred in 9 of the 19 patients; one of them relapsed twice (case No. 2). Relapse took place after cessation of steroid therapy in four cases (Nos. 2, 4, 10 and 12) and during tapering in five (table $3)$. All nine patients still had a dramatic response when corticotherapy was reintroduced or increased.

Long-term evolution. Mean \pm SEM follow-up was $49 \pm 44$ months (range 12-142 months). Eleven of the 19 patients had maintenance therapy (table 2), including systemic and inhaled corticotherapy in six, systemic corticotherapy in

Table 2. - Long-term evolution of CEP

\begin{tabular}{|c|c|c|c|c|c|c|c|c|c|c|}
\hline \multirow{2}{*}{$\begin{array}{l}\mathrm{Pt} \\
\text { No. }\end{array}$} & \multirow[t]{2}{*}{$\mathrm{Gp}$} & \multirow{2}{*}{$\begin{array}{l}\text { Previous } \\
\text { asthma* }\end{array}$} & \multirow{2}{*}{$\begin{array}{l}\text { Wheezing } \\
\text { at diagnosis }\end{array}$} & \multirow{2}{*}{$\begin{array}{l}\text { First } \\
\text { LFT }\end{array}$} & \multirow{2}{*}{$\begin{array}{l}\text { Follow-up } \\
\text { LFT }\end{array}$} & \multirow[t]{2}{*}{ Relapse** } & \multirow{2}{*}{$\begin{array}{l}\text { Recurrent } \\
\text { eosinophilia }\end{array}$} & \multicolumn{2}{|c|}{ Maintenance steroid therapy } & \multirow{2}{*}{$\begin{array}{c}\text { Duration of } \\
\text { follow-up } \\
\text { months }\end{array}$} \\
\hline & & & & & & & & $\begin{array}{c}\text { oral }(\mathrm{mg})^{\$} \\
\text { No }\end{array}$ & $\begin{array}{c}\text { Inhaled } \\
\text { No }\end{array}$ & \\
\hline 1 & A & Yes & No & $\mathrm{R}$ & $\mathrm{N}$ & 0 & No & No & No & 117 \\
\hline 2 & A & Yes & Yes & $\mathrm{R}$ & $\mathrm{R}$ & 2 & No & No & No & 135 \\
\hline 3 & A & No & No & $\mathrm{R}$ & $\mathrm{N}$ & 0 & No & No & No & 32 \\
\hline 4 & A & No & Yes & $\mathrm{O}$ & $\mathrm{N}$ & 1 & Yes & No & No & 12 \\
\hline 5 & A & No & No & $\mathrm{N}$ & $\mathrm{N}$ & 1 & Yes & Yes (2.5) & No & 12 \\
\hline 6 & A & No & Yes & $\mathrm{N}^{\#}$ & $\mathrm{~N}$ & 1 & No & No & No & 12 \\
\hline 7 & A & Yes & Yes & $\mathrm{O}$ & $\mathrm{N}$ & 0 & No & No & No & 12 \\
\hline 8 & A & Yes & No & $\mathrm{R}$ & $\mathrm{N}$ & 0 & No & Yes (4) & No & 12 \\
\hline 9 & A & No & No & $\mathrm{R}$ & $\mathrm{N}$ & 1 & No & No & No & 41 \\
\hline 10 & B & No & No & $\mathrm{R}$ & $\mathrm{O}$ & 1 & Yes & No & Yes & 142 \\
\hline 11 & B & Yes & Yes & $\mathrm{N}$ & $\mathrm{O}$ & 1 & Yes & Yes (16) & Yes & 91 \\
\hline 12 & B & Yes & No & $\mathrm{N}$ & $\mathrm{O}$ & 1 & No & No & No & 48 \\
\hline 13 & B & No & No & $\mathrm{N}$ & $\mathrm{N} \ddagger$ & 0 & No & Yes (20) & Yes & 72 \\
\hline 14 & B & No & No & $\mathrm{O}$ & $\mathrm{O}$ & 0 & No & Yes (10) & Yes & 46 \\
\hline 15 & B & No & No & $\mathrm{R}$ & $\mathrm{O}$ & 0 & Yes & Yes (10) & Yes & 47 \\
\hline 16 & B & No & No & $\mathrm{N}^{\#}$ & $\mathrm{O}$ & 0 & Yes & Yes (12.5) & Yes & 46 \\
\hline 17 & B & No & No & $\mathrm{R}$ & $\mathrm{O}$ & 0 & No & Yes (16) & No & 18 \\
\hline 18 & B & Yes & Yes & $\mathrm{O}$ & $\mathrm{O}$ & 0 & No & No & Yes & 13 \\
\hline 19 & B & No & No & $\mathrm{R}$ & $\mathrm{O}$ & 1 & Yes & Yes (15) & Yes & 22 \\
\hline
\end{tabular}

*: asthma evolving for at least 1 year before diagnosis of CEP; **: relapse is defined by the association of clinical and/or radiological signs; \$: mg prednisolone in parenthesis; \#: lung function test was performed after initiating corticotherapy, which can explain normal results; $\$$ : typical asthma on treatment with systemic and inhaled steroid therapy, and long-acting $\beta_{2}$-agonists. CEP: chronic eosinophilic pneumonia; Pt: patient; Gp: Group; LFT: lung function test; R: restrictive; O: obstructive; N: normal. 
Table 3. - Evolution under initial corticotherapy, until first relapse episode or disruption without any relapse

\begin{tabular}{|c|c|c|c|c|c|c|c|}
\hline $\begin{array}{l}\mathrm{Pt} \\
\text { No. }\end{array}$ & $\mathrm{Gp}$ & $\begin{array}{c}\text { Initial dose } \\
\text { of prednisolone } \\
\text { mg }\end{array}$ & $\begin{array}{c}\text { Initial } \\
\text { evolution }\end{array}$ & $\begin{array}{c}\text { Prednisolone dose } \\
\text { at relapse } \\
\text { mg }\end{array}$ & $\begin{array}{c}\text { Time between stop } \\
\text { and relapse } \\
\text { months }\end{array}$ & $\begin{array}{c}\text { Relapses } \\
\text { n }\end{array}$ & $\begin{array}{c}\text { Duration of } \\
\text { initial treatment } \\
\text { months }\end{array}$ \\
\hline 1 & A & 65 & DI & - & - & 0 & 24 \\
\hline 2 & A & 60 & DI & 0 & 30 & 2 & 30 \\
\hline 3 & A & 30 & DI & - & - & 0 & 7 \\
\hline 4 & A & 60 & DI & 0 & 3 & 1 & 3 \\
\hline 5 & A & 60 & DI & 1 & - & 1 & 9 \\
\hline 6 & A & 60 & DI & 5 & - & 1 & 12 \\
\hline 7 & A & 60 & DI & - & - & 0 & 3 \\
\hline 8 & A & 30 & DI & - & - & 0 & 6 \\
\hline 9 & A & 80 & DI & 8 & - & 1 & 3 \\
\hline 10 & B & 30 & DI & 0 & 18 & 1 & 12 \\
\hline 11 & B & 30 & DI & 10 & - & 1 & 15 \\
\hline 12 & B & 30 & DI & 0 & 4 & 1 & 6 \\
\hline 13 & B & 30 & DI & - & - & 0 & 72 \\
\hline 14 & B & 60 & DI & - & - & 0 & 46 \\
\hline 15 & B & 60 & DI & - & - & 0 & 48 \\
\hline 16 & B & 20 & DI & - & - & 0 & 30 \\
\hline 17 & B & 65 & PI & - & - & 0 & 7 \\
\hline 18 & B & 60 & DI & - & - & 0 & 4 \\
\hline 19 & B & 65 & PI & 12.5 & - & 1 & 4 \\
\hline
\end{tabular}

\#: until first relapse or disruption. Pt: patient; Gp: Group; DI: dramatic improvement; PI: partial improvement.

only three, and inhaled corticotherapy in only two. Mean \pm SEM dose of systemic corticotherapy at follow-up was $11.8 \pm 5.45 \mathrm{mg}$ of prednisone.

The last evaluation of the 19 patients showed that total recovery from restrictive lung function was seen in nine patients (Nos. 1-9; "Group A") with normal clinical data. Patients No. 1 and Nos. 3-9 had normal lung function at follow-up. One patient (No. 2) developed bilateral apical lung fibrosis with restrictive lung function (FVC 50\% pred and FEV1 55\% pred).

The remaining 10 patients (Nos. 10-19; "Group B") had a less favourable course (table 4). Despite initial improvement, three patients (Nos. 13, 16 and 18) exhibited typical asthma with paroxysmal dyspnoea and wheezing. Seven patients were asymptomatic and had intermittent wheezing on chest examination. Nasal polyps, requiring local corticotherapy, were diagnosed during the follow-up in 3 of the 10 patients (Nos. 14-16), one of them (No. 16) having a previous history of polyps. Results of lung function tests were abnormal in all but one of these 10 patients, demonstrating obstructive lung function as defined in the ATS statement [8], with concomitant small airways disease. FEF25-75 ranged 35$105 \%$ pred (mean \pm SEM $49 \pm 21 \%$ pred). $\beta_{2}$-mimetic test showed a significant reversibility of bronchial obstruction in seven patients. Patient No. 13 who exhibited normal lung function findings was treated with systemic and inhaled corticotherapy combined with long-acting $\beta_{2}$-agonists because of obvious asthma. These 10 patients did not fulfil the criteria defining usual CEP relapses, none of them having general symptoms or chest radiographic abnormality. Recurrent eosinophilia was present in 5 cases (Nos. 10, 11, 15, 16 and 19).

\section{Relationship between initial presentation and long-term} occurrence of obstructive pulmonary disease (table 5)

We considered two groups of patients as defined above. Nine patients had a total recovery or restrictive pattern at follow-up (Group A) and 10 patients exhibited an obstructive pattern (Group B). No statistical difference

Table 4. - Pulmonary function tests in patients with obstructive airway disease at the time of follow-up (Group B)

\begin{tabular}{|c|c|c|c|c|c|c|c|c|c|c|c|c|c|c|}
\hline \multirow{2}{*}{$\begin{array}{l}\mathrm{Pt} \\
\text { No. } \\
10\end{array}$} & \multirow{2}{*}{$\begin{array}{c}\begin{array}{c}\text { Duration of } \\
\text { follow-up } \\
\text { months }\end{array} \\
142\end{array}$} & \multicolumn{2}{|c|}{$\begin{array}{c}\text { FVC } \\
\text { L \% pred }\end{array}$} & \multicolumn{2}{|c|}{$\begin{array}{c}\text { FEV1 } \\
\text { L \% pred }\end{array}$} & \multirow{2}{*}{$\begin{array}{c}\text { FEV } 1 / \mathrm{FVC} \\
\% \\
66\end{array}$} & \multirow{2}{*}{$\begin{array}{c}\text { Post- } \beta_{2} \\
\text { FEV1 L } \\
2.15\end{array}$} & \multicolumn{2}{|c|}{$\begin{array}{c}\triangle \mathrm{FEV} 1 \\
\mathrm{~L} \%\end{array}$} & \multicolumn{2}{|c|}{$\begin{array}{l}\text { FEF25-75 } \\
\text { L \% pred }\end{array}$} & \multirow{2}{*}{$\begin{array}{c}\text { Post- } \beta_{2} \\
\text { FEF25-75 } \\
\text { L } \\
1.59\end{array}$} & \multicolumn{2}{|c|}{$\begin{array}{c}\Delta \mathrm{FEF} 25-75 \\
\mathrm{~L} \%\end{array}$} \\
\hline & & 2.91 & 99 & 1.92 & 77 & & & 0.23 & 12 & 1.10 & 36 & & 0.49 & 44 \\
\hline 11 & 91 & 3.17 & 102 & 2.41 & 91 & 76 & NA & & & 1.57 & 59 & NA & & \\
\hline 12 & 48 & 2.74 & 128 & 2.03 & 114 & 74 & 2.04 & 0.10 & 0 & 1.47 & 54 & 2.01 & 0.54 & 37 \\
\hline 13 & 72 & 5.75 & 116 & 4.93 & 117 & 86 & 5.04 & 0.11 & 2 & 5.18 & 105 & 5.46 & 0.28 & 5 \\
\hline 14 & 46 & 3.47 & 95 & 2.27 & 72 & 65 & 2.61 & 0.34 & 15 & 1.32 & 36 & 1.78 & 0.46 & 35 \\
\hline 15 & 47 & 3.36 & 88 & 2.28 & 68 & 68 & 2.67 & 0.39 & 17 & 1.45 & 36 & 2.41 & 0.96 & 66 \\
\hline 16 & 44 & 3.31 & 106 & 2.49 & 92 & 75 & 2.83 & 0.34 & 14 & 1.96 & 56 & 2.92 & 0.96 & 49 \\
\hline 17 & 18 & 2.19 & 85 & 1.51 & 69 & 69 & 1.73 & 0.22 & 14 & 0.86 & 37 & 1.25 & 0.39 & 45 \\
\hline 18 & 13 & 2.68 & 102 & 1.67 & 76 & 62 & 2.15 & 0.48 & 29 & 1.07 & 37 & 1.29 & 0.22 & 20 \\
\hline 19 & 22 & 1.92 & 69 & 1.38 & 59 & 72 & 1.56 & 0.18 & 13 & 0.95 & 35 & 1.54 & 0.59 & 62 \\
\hline
\end{tabular}

PT: patient; FVC: forced vital capacity; \% pred: percentage of predicted value; FEV1: forced expiratory volume in one second; Post- $\beta_{2}$ : post- $\beta_{2}$-mimetic; $\Delta$ : difference in; FEF25-75: forced mid-expiratory flow; $\%$ pred: $\%$ of predicted value; NA: not available.. 
Table 5. - Comparison between initial presentation of patients with total recovery (Group A) and patients with chronic obstructive lung disease at follow-up (Group B)

\begin{tabular}{|c|c|c|}
\hline & Group A & Group B \\
\hline Patients $\mathrm{n}$ & 9 & 10 \\
\hline Age yrs & $57 \pm 5$ & $46 \pm 5$ \\
\hline $\begin{array}{l}\text { Previous asthma or } \\
\text { rhinitis } n\end{array}$ & 5 & 7 \\
\hline Serum IgE level $\mathrm{kU} \cdot \mathrm{L}^{-1}$ & $671 \pm 325$ & $500 \pm 154$ \\
\hline Eosinophil count cells $\cdot \mathrm{mm}^{-3}$ & $4406 \pm 1560$ & $4075 \pm 666$ \\
\hline BAL eosinophilia§ \% & $38 \pm 6$ & $65 \pm 11 *$ \\
\hline Duration of follow-up months & $43 \pm 16$ & $54 \pm 12$ \\
\hline
\end{tabular}

When applicable, results are expressed as mean \pm sEM. $\S$ : BAL was obtained in all patients in Group A and 8 out of 10 patients in Group B. IgE: immunoglobulin E; BAL: bronchoalveolar lavage. *: $\mathrm{p}=0.05$, compared to Group A, nonparametric Mann-Whitney U-test.

was found concerning age, initial serum IgE level, initial blood eosinophil count, and duration of follow-up. Initial BAL eosinophilia was higher in Group B than in Group A ( $\mathrm{p}=0.05)$. Interestingly, the occurrence of an obstructive lung disease was not related to a previous history of asthma or rhinitis (A/R). Three out of 7 patients without pre-existing $\mathrm{A} / \mathrm{R}$ developed an obstructive lung disease, as well as 7 out of 12 patients with pre-existing $\mathrm{A} / \mathrm{R}(\mathrm{p}=\mathrm{NS}$; chi-squared test).

\section{Discussion}

We have retrospectively analysed 19 patients with CEP, whose epidemiological, clinical, biological and radiological features are in agreement with the literature $[1,3,4,10]$. The study demonstrates that the development of an obstructive ventilatory defect is a common finding during the course of CEP, and that bronchial obstruction might appear despite the absence of clinical and radiological signs of relapse. Finally, a markedly increased BAL eosinophilia at initial evaluation was associated with a higher risk of development of bronchial obstruction.

The long-term prognosis of CEP is usually good, with complete recovery in a few days and a favourable longterm course, as shown by NAUGHTON et al. [5] in a recent series of 12 cases with a mean follow-up of 10.2 yrs. Relapses, as defined by recurrence of clinical and radiological signs, were common in the present study, occurring in nine patients (45\%), including a single episode in eight and multiple relapses in one patient. The frequency of multiple relapses has been underlined previously [5]. It is likely that the number of relapses in the study by NAUGHTON et al. [5] was linked to a longer follow-up (10.2 yrs).

Obstructive airways disease was present in 10 patients $(55 \%)$ during the follow-up. Three of these exhibited typical severe asthma, as previously reported by BANCAL et al. [11]. He suggested a correlation between high serum IgE level and severity of asthma. The prognostic relevance of elevated serum IgE level is still discussed [12], and we found no significant association between initial serum IgE levels and functional outcome. Small airway disease is an unusual feature [10], which was present in 7 out of 19 patients $(37 \%)$. Fox and SEED [10] suggested that bronchiolitis obliterans at the time of initial presentation might explain persistent small airways obstruction. Conversely, interstitial eosinophilic infiltration without bronchiolitis might result in a total recovery under steroid treatment. In the present series, a symptom-free period and a complete reversibility of the bronchial obstruction was detected in the 10 obstructive patients. These findings are in contrast to the supposition of Fox and SEED [10] of an evolving bronchiolitis obliterans.

The present results suggest that eosinophils may play a role in the pathogenesis of bronchial obstruction in CEP. Recurrent blood eosinophilia occurred in 5 out of 7 patients with small airways disease; one patient (No. 10) exhibited eosinophilic bronchitis on pathological examination at that time. PADOVANI et al. [13] followed a patient with CEP and obstructive lung function over a period of 12 months. Peak expiratory flow (PEF), blood eosinophilia and serum eosinophil cationic protein (ECP) measurements showed opposite variations, with increased blood eosinophilia and serum ECP level as PEF decreased and respiratory symptoms occurred. Moreover, initial BAL eosinophilia tended to be higher in the group of patients who developed an obstructive impairment of the pulmonary function during the follow-up. Further studies should analyse the evolution of the BAL cell profile in order to specify the role of bronchial eosinophilia in functional impairment during the course of CEP. Moreover, the dosage of eosinophil proteins in BAL should be of particular interest, in order to assess eosinophil activation in such patients with an obstructive pattern.

These results support the heterogeneity of CEP outcome, and make its good prognosis doubtful. The classic definition of relapses has to be questioned. Usual criteria, including recurrence of clinical and radiological signs, fail to identify patients with isolated obstructive airway disease. When present, concurrent peripheral and/or BAL eosinophilia argues for CEP manifestations. At the present time, asthma-related symptoms must be considered to be a usual feature of CEP outcome. As a consequence, CEP management has to include not only clinical and radiological examination but also a blood eosinophil count and pulmonary function tests. BAL should be performed when obstructive pulmonary disease is the only sign of relapse, in order to ascertain lung eosinophilia and CEP progression. Prospectively controlled evaluation of inhaled steroid therapy associated with systemic steroid therapy should be performed to better determine whether long-term inhaled steroid therapy may prevent the development of obstructive ventilatory defect in the course of chronic pneumonia.

Members of the GEPI: F. Bart (Bethune, France), S. Beaujot (Cambrai, France), A. Benard (Roubaix, France), J.F. Bervar (Arras, France), J. Broux (Liège, Belgium), E. Cardot (Bethune, France), B. Chevalon (Lens, France), E. Dansin (Lille, France), P. Degive (Seraing, Belgium), L. Delaunois (Mont-Godinne, Belgium), E. Delepoulle (Lens, France), G. Demarcq (Valenciennes, France), C. Deroubaix (Dunkerque, France), J. Durieu (Lille, France), A. Duthoit (Roubaix, France), M. Florin (Douai, France), X. Ficheroulle (Tourcoing, France), F. Fortin (Lille, France), B. Fourquet (Calais, France), J.P. Grignet (Denain, France), J.M. Grosbois (Lille, France), M. Gustin (Liège, Belgium), F. Herengt (Arras, France), J.J. Lafitte (Lille, France), Y. Lierman (Arras, France), C.H. Marquette (Lille, France), E. Maetz (Douai, France), B. Mellin (Dunkerque, France), H. Monnot (Helfaux, France), F. Pagnier (Somain, France), T. Perez (Lille, France), E. 
Rademacker (Liège. Belgium), Ph. Ramon (Lille, France), J.P. Roux (Valenciennes, France), B. Stach (Valenciennes, France), F. Steenhouwer (Roubaix, France), J. Soots (Bethune, France), V. Tack (Calais, France), I. Tillie-Leblond (Lille, France), A.B. Tonnel (Lille, France), C. Tulippe (Mouscron, Belgium), C. Van Parys (Peuwelz, Belgium), F. Varlet (Bethune, France), B. Wallaert (Lille, France), C. Wallaert (Lens, France).

\section{References}

1. Carrington $\mathrm{CB}$, Addington WW, Goff AM, et al. Chronic eosinophilic pneumonia. N Engl J Med 1969; 280: $787-$ 798.

2. Liebow AA, Carrington CB. The eosinophilic pneumonias. Medicine 1969; 48: 251-285.

3. Durieu J, Wallaert B, Tonnel AB. La pneumonie chronique à éosinophiles ou maladie de Carrington. Rev Mal Respir 1993; 10: 499-507.

4. Jederlinic PJ, Sicilian L, Gaensler EA. Chronic eosinophilic pneumonia. Medicine 1988; 67: 154-162.

5. Naughton M, Fahy J, FitzGerald MX. Chronic eosinophilic pneumonia: a long-term follow-up of 12 patients Chest 1993; 103: 162-165.

6. Klech H, and the European Society of Pneumology Task Group on BAL. Technical recommendations and guide- lines for bronchoalveolar lavage (BAL). Eur Respir $J$ 1989; 2: 561-585.

7. American Thoracic Society. Standardization of spirometry. 1987 update. Am Rev Respir Dis 1987; 136: 1285-1298.

8. American Thoracic Society. Medical section of the American Lung Association. Lung function testing: selection of reference values and interpretative strategies. Am Rev Respir Dis 1991; 144: 1202-1218.

9. American College of Chest Physicians. Committee report: criteria for the assessment of reversibility in airways obstruction. Report of the committee on emphysema. Chest 1974; 65: 552-553.

10. Fox B, Seed WA. Chronic eosinophilic pneumonia. Thorax 1980; 35: 570-580.

11. Bancal C, Sadoun D, Valeyre D, et al. Pneumopathie chronique idiopathique à éosinophiles. Presse Méd 1989; 18: $1695-1698$

12. Gonzalez EB, Hayes D, Weedn VW. Chronic eosinophilic pneumonia (Carrington's) with increased IgE levels. Arch Intern Med 1988; 148: 2622-2624.

13. Padovani M, Tillie-Leblond I, Wallaert B, Tonnel AB. Intérêt du dosage de la protéine cationique de l'éosinophile sérique au cours des pneumopathies hyperéosinophiliques. Rev Mal Respir 1995; 12 (Suppl. 2): R55. 